\title{
Studies on the Infection and the Multiplication of Plant Viruses
}

\author{
IV. Suppression of cellular RNA synthesis by the cucumber \\ mosaic virus-infection*
}

\author{
Sakari KATo** and Tadao MisAwA** \\ 加藤 盛**.三沢正生**: 植物ウイルスの感染と增殖に関する研究 \\ IV. CMV 感染による細胞 RNA 合成の抑制*
}

\begin{abstract}
1) The cellular RNA content was altered by CMV infection. The amount of RNA in the infected cells decreased during the first $24 \mathrm{hr}$ after infection, and thereafter increased gradually. It is conceivable that the reduction in RNA content in the early stage of infection resulted from the suppression of cellular RNA synthesis, and that the increase in RNA in the later stage was due to the increase of viral RNA in the cells.

2) Base composition and buoyant density of DNA were not significantly altered by infection. The suppression of cellular RNA synthesis by CMV seems not to be caused by a compositional change of DNA.

3) The rate of histone synthesis changed concurrently with the changes in the rate of DNA synthesis. The change in histone synthesis was not only quantitative but also qualitative; the fractionation of histone revealed a preferential increase in arginine-rich histone fraction.

4) RNA synthesis in isolated calf thymus nuclei was suppressed by the addition of tobacco histone. This inhibitory effect was greater in histone from infected cells than in that from normal cells.

5) These results suggest that the suppression of cellular RNA synthesis by infection is due to the compositional change of histone.
\end{abstract}

(Received April 19, 1971)

\section{Introduction}

It has been shown that the synthesis of normal cell RNA and protein is inhibited in poliovirus infection of HeLa cells ${ }^{8,9)}$, mengovirus infection of mouse cells $\mathrm{s}^{4)}$ and others $\mathrm{s}^{3,6,7,21)}$. There are many reports that have been concerned with the mechanism for the suppression of cellular RNA synthesis evoked by viral infection. Baltimore and Franklin ${ }^{4)}$ and Holland ${ }^{8)}$ found that the aggregate enzyme (DNA-protein complex containing RNA polymerase) ${ }^{22}$ ) activity is reduced in the virus infected cell. Holland ${ }^{9}$ reported that failure of polymerase synthesis alone cannot be the sole explanation for the repression of normal RNA synthesis in poliovirus

* A part of this paper was read before the annual meeting of Phytopathological Society of Japan in April, 1967. This work was supported, in part, by grant from the Ministry of Education.

** Faculty of Agriculture, Tohoku University, Sendai, Japan. 東北大学農学部 
infected cells. Furthermore, he believes that depression of cell RNA synthesis cannot be attributed to DNA breakdown, nor to a film masking the priming ability of DNA, and that the production of loosely bound material capable of masking cannot be ruled out. The precise mechanism for the suppression of the normal cellular RNA and protein synthesis in the cells infected with viruses is not fully understood. Huang and Bonner ${ }^{10)}$, working with pea seedling, have postulated that the histone with which DNA is combined in the genetic material of higher organisms has as one of its roles the regulation of DNA-dependent RNA synthesis. In subsequent papers, Allfrey et al. ${ }^{2}$, working with calf thymus histone, reported similar results.

Previous wor $\mathrm{k}^{17)}$ in our laboratory demonstrated a temporary increase of the histone in tobacco leaf cells soon after infection.

The purpose of this investigation was to determine if the histone plays a role in the regulation of cellular RNA synthesis in virus-infected tobacco tissue.

\section{Materials and methods}

\section{Test plant}

Tobacco plants (Nicotiana tabacum var. Bright Yellow) which were grown in a growth cabinet (day at $28^{\circ} \mathrm{C}$ and night at $25^{\circ} \mathrm{C}$ at about $80 \%$ humidity; intensity of illumination, 12,000 lux; day length, $12 \mathrm{hr}$ ) were used at the 15 th leaf stage.

\section{Virus}

The virus used in the experiment was the ordinary strain of cucumber mosaic virus (CMV). Inoculum was obtained by grinding and squeezing the inoculated tobacco leaves with a $0.1 \mathrm{M}$ phosphate buffer at $\mathrm{pH} 7.0$. Inoculation by CMV was applied on the upper surface of the expanded leaves of tobacco plants by the carborundum method. For the control, identically grown plants were rubbed with the healthy leaf extract in the same manner. Control and inoculated plants were held in the growth cabinet as cited above.

Extraction and determination of whole RNA in the cell

The RNA of tobacco leaves was extracted in cold PCA according to the method of Ogur and $\operatorname{Rosen}^{19)}$ and the amount was determined by the orcinol reaction ${ }^{12)}$.

\section{Preparation of DNA}

Tobacco leaves were ground in a glass homogenizer. DNA was extracted by a modification of the method of Marmur ${ }^{14)}$; in order to remove proteins, $\mathrm{CHC1}_{3}$-octanol and phenol were used before the addition of $1 \mathrm{M} \mathrm{NaClO}_{3}$, and further deproteinization was made with $\mathrm{CHC1}_{3}$ octanol $(24: 1 \mathrm{v} / \mathrm{v})$. The purine and pyrimidine composition of DNA was determined by the method of Marshak and Vogel ${ }^{15)}$.

\section{CsCl density gradient centrifugation of DNA}

The DNA was centrifuged in a $\mathrm{CsC} 1$ density gradient for $48 \mathrm{hr}$ at $36,000 \mathrm{rpm}$ in the RPS 40 rotor of a Hitachi $55 \mathrm{P}$ centrifuge. After centrifugation, the bottom of the tubes was punctured to obtain contents. The optical density of the material at $260 \mathrm{~m} \mu$ was measured by a spectrophotometer.

\section{Estimation of histone-decomplexed DNA (free DNA)}

The free DNA was estimated by subtracting the DNA in the nucleoprotein from the total chromatin DNA values. The nucleoprotein was prepared from the chromatin fraction following the method of Zubay and Doty ${ }^{23)}$.

Measurement of histone in the nucleus

Samples were excised from inoculated leaves successively after the inoculation. The 


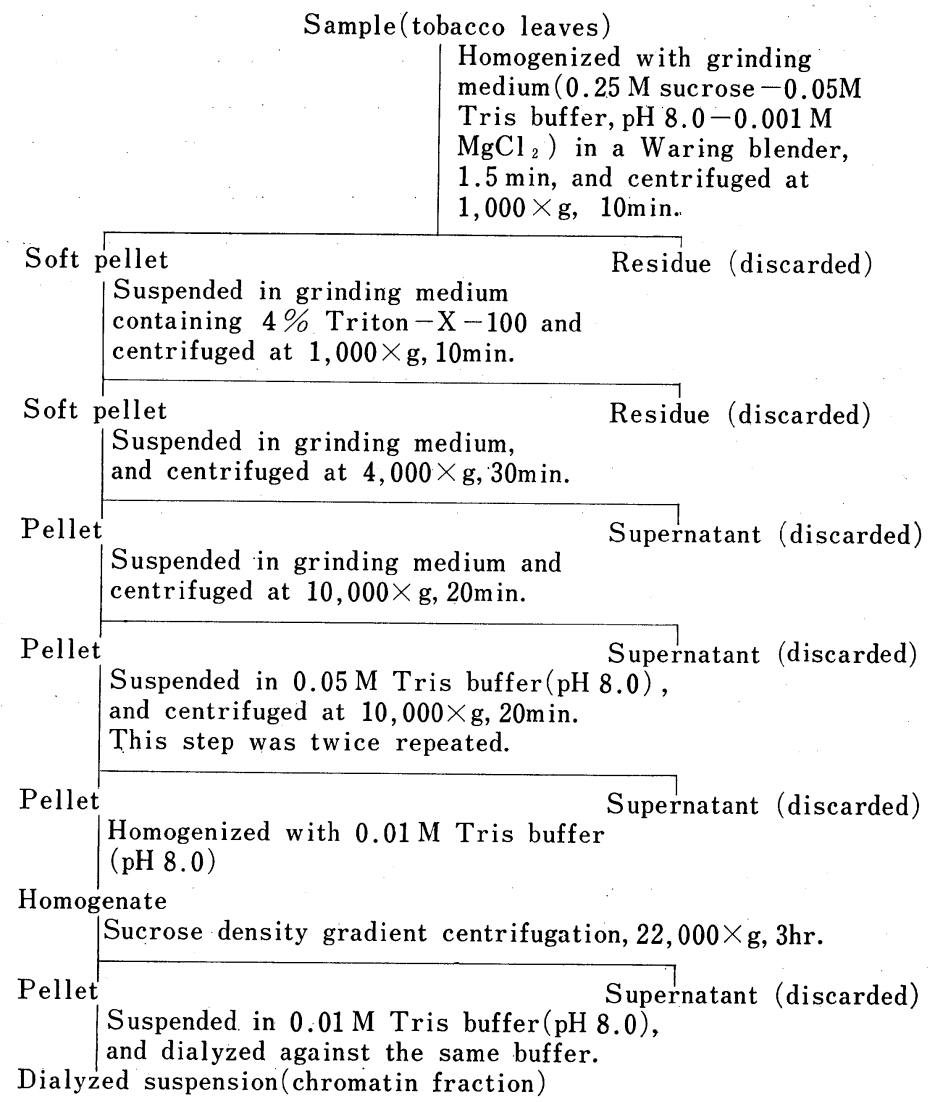

Fig. 1. Isolation of chromatin.

samples were fixed for $24 \mathrm{hr}$ in $10 \%$ neutral formalin, washed overnight in running tap water, dehydrated and embedded in paraffin and cut into sections of $10 \mu$ width. These sections were stained with Fast green FCF by the method of Alfert and Geschwind ${ }^{1)}$. The measurements were made on 400-500 nuclei of parenchyma cells after the two wavelength method of Mendelson ${ }^{16)}$, using a microspectrophotometer (Olympus Co. model IV).

\section{Preparation of histone}

For the preparation of tobacco leaf chromatin the method of Huang and Bonner ${ }^{10)}$ was used with a slight modification as shown in Fig. 1. The isolated chromatin was suspended in cold $0.01 \mathrm{M}$ Tris-HC1 buffer ( $\mathrm{pH} 8.0$ ), and stirred in ice water to which one-fourth volume of cold $1 \mathrm{~N} \mathrm{H}_{2} \mathrm{SO}_{4}$ was added slowly. After $30 \mathrm{~min}$ the sediment was broken up and extracted with $0.4 \mathrm{~N} \mathrm{H}_{2} \mathrm{SO}_{4}$ (one-half the final volume of the first extract) and the histone sulfate precipitated quantitatively at $-20^{\circ} \mathrm{C}$ for $36 \mathrm{hr}$. The histone sulfate was recovered by centrifugation, washed three times with ethanol, and dried in a vacuum desiccator.

\section{Amino acid analysis}

Histone samples ( $3 \mathrm{mg}$ ) were hydrolyzed in $2 \mathrm{ml}$ of constant boiling $6 \mathrm{~N}$ HC1 solution in evacuated, sealed tubes for $22 \mathrm{hr}$ at $105^{\circ} \mathrm{C}$. The amino acid analysis was performed using a Hitachi automatic amino acid analyzer.

\section{Disk electrophoresis of histone}

Disk electrophoresis of histone was carried out by the method of Reisfeld et al. ${ }^{20)}$. Acid- 
extracted histones were dissolved in 2 parts $\beta$-alanine-acetic acid buffer $(3.2 \% \beta$-alanine and $0.8 \%$ glacial acetic acid) at $\mathrm{pH} 4.0$, and one part $1.7 \mathrm{M}$ sucrose. A sample was applied to a gel. Acrylamide gel was made from $0.5 \%$ of tetraethylenediamine, $15 \%$ acrylamide, $0.1 \%$ methylenbisacrylamide with $0.14 \%$ ammonium persulfate as catalyst. Electrophoresis was carried out at a constant current of $5 \mathrm{~mA}$ per tube, for $1.5 \mathrm{hr}$ at room temperature. Gels were stained by $7 \%$ acetic acid solution containing $1 \%$ amidoblack $10 \mathrm{~B}$. After staining, the gels were destained by electrophoresis in $7 \%$ acetic acid solution. The histone bands of gels were photographed. Films were printed and subjected to densitometric analysis.

\section{Fractionation of histone}

Histone was fractionated on a carboxymethylcellulose column after the method of Johns et al. ${ }^{11)}$ The histone was dissolved in buffer ( $\mathrm{pH} 4.2$ ) containing $0.1 \mathrm{M}$ acetic acid and $0.03 \mathrm{M}$ $\mathrm{NaOH}$, and then applied to a column. Elution was carried out in four steps as follows: (1) a buffer ( $\mathrm{pH} 4.2$ ) containing $0.1 \mathrm{M}$ acetic acid and $0.03 \mathrm{M} \mathrm{NaOH}$, (2) a buffer ( $\mathrm{pH} 4.2$ ) containing $0.17 \mathrm{M}$ acetic acid, $0.051 \mathrm{M} \mathrm{NaOH}$ and $0.42 \mathrm{M} \mathrm{NaC1}$, (3) $0.01 \mathrm{~N} \mathrm{HC1}$, and (4) $0.02 \mathrm{~N} \mathrm{HC1}$. Each elute of $5 \mathrm{~m} l$ was collected automatically at a flow rate of about $0.5 \mathrm{~m} l / \mathrm{min}$. Protein content in each elute was determined by absorption at $280 \mathrm{~m} \mu$ or by the method of Lowry et al. ${ }^{13)}$

\section{Preparation of labeled tobacco histone}

Tobacco disks were cut from leaves with a cork borer and were incubated for $6 \mathrm{hr}$ in Petri-dish, each of which contained distilled water containing $0.1 \mu \mathrm{c} / \mathrm{m} l$ of ${ }_{\mathrm{L}}{ }^{14} \mathrm{C}$-leucine. After the incubation, the leaf disks were washed with distilled water. Chromatin was isolated by the method of Huang and Bonner ${ }^{10)}$. Untreated leaves were added as a carrier. Histone was isolated from the purified chromatin as described above and then fractionated on a carboxymethylcellulose column. The histone in each fraction was precipitated by trichloroacetic acid. The precipitates were washed 4 times with $5 \%$ trichloroacetic acid; this was followed by 3 washes with $80 \%$ acetone and for radioactivity measurements, an aliquot of each $0.5 \mathrm{~m} l$ was transferred to scintillation vials. The vials were filled with $15 \mathrm{~m} l$ of scintillator solution containing $4 \mathrm{~g}$ of 2,5-diphenyloxazol (PPO), $50 \mathrm{mg}$ of 1,4-bis-2-(5-phenyl-oxazolyl)-benzene (POPOP), $120 \mathrm{~g}$ of naphthalene, $20 \mathrm{~g}$ of Cab-O-Sil (Packard) and dioxane per liter. The radioactivity was measured with a liquid scintillation spectrometer (Packard 2311).

\section{Effect of histone on the RNA synthesis}

All experimental procedures employed were similar to those described by Allfrey et al..$^{2}$, except that tobacco histone was substituted for thymus histone.

\section{Results}

\section{Suppression of cellular RNA synthesis in CMV infected tobacco cells}

In a previous paper ${ }^{17)}$ it was shown that the CMV-infection altered nucleolar RNA synthesis. In the present experiment, the RNA content was studied using CMV infected leaves. The results are shown in Fig. 2. The RNA content of infected cells decreased about $40 \%$ during the first $24 \mathrm{hr}$ after the inoculation and thereafter increased gradually. But, the level of RNA remained below that of the control value and began to decrease again after 96 $\mathrm{hr}$. The increase in the amount of RNA after $24 \mathrm{hr}$ appears to be due to the increase of viral RNA within the infected cells, but not due to the restoration of cellular RNA synthesis. Since unpublished data in our laboratory indicate that most RNA synthesis during CMV infection is in fact virus-directed, it appears likely that immediately after infection cellular RNA synthesis is inhibited irreversibly in the ceil. 
Table 1. Base composition of nuclear DNA from healthy and infected tobacco leaves

\begin{tabular}{lccccc}
\hline \multirow{2}{*}{ Isolated DNA } & \multicolumn{4}{c}{ Molar ratios calculated to a total of 100} \\
& Adenine & Guanine & Cytosine & Thymine & $\mathrm{A}+\mathrm{T} / \mathrm{G}+\mathrm{C}$ \\
\hline Healthy & 31.0 & 19.5 & 20.1 & 29.4 & 1.52 \\
8 hr after inoculation & 32.1 & 18.6 & 17.7 & 31.6 & 1.75 \\
72 hr after inoculation & 31.9 & 19.5 & 18.2 & 30.4 & 1.65 \\
\hline
\end{tabular}

Table 2. Proportions of DNA present in tobacco cell nucleus as the histone-complexed and histone-decomplexed (free) forms

\begin{tabular}{|c|c|c|c|c|c|c|}
\hline $\begin{array}{l}\text { Time after } \\
\text { inoculation }\end{array}$ & Fraction & $\begin{array}{l}\text { Histone } \\
\text { content }^{\mathrm{a}}\end{array}$ & $\begin{array}{l}\text { DNA } \\
\text { content }\end{array}$ & $\begin{array}{l}\text { Histone/ } \\
\text { DNA }\end{array}$ & $\begin{array}{l}\text { Free DNA } \\
\text { contenta) }\end{array}$ & $\begin{array}{l}\text { Histone complexed } \\
\text { DNA/Total DNA }\end{array}$ \\
\hline \multirow{2}{*}{ Control } & Nucleo-protein & 13.8 & 9.71 & 1.42 & \multirow{2}{*}{2.15} & \multirow{2}{*}{ - } \\
\hline & Nucleus & 14.0 & 11.86 & 1.18 & & \\
\hline \multirow{2}{*}{$10 \mathrm{~min}$} & Nucleo-protein & 13.3 & 9.23 & 1.44 & \multirow{2}{*}{2.46} & \multirow{2}{*}{0.78} \\
\hline & Nucleus & 13.1 & 11.69 & 1.12 & & \\
\hline \multirow{2}{*}{$8 \mathrm{hr}$} & Nucleo-protein & 17.5 & 12.00 & 1.46 & \multirow{2}{*}{2.57} & \multirow{2}{*}{0.82} \\
\hline & Nucleus & 17.5 & 14.57 & 1.20 & & \\
\hline
\end{tabular}

a) $\mu \mathrm{g}$ per $10 \mathrm{~g}$ fresh weight.

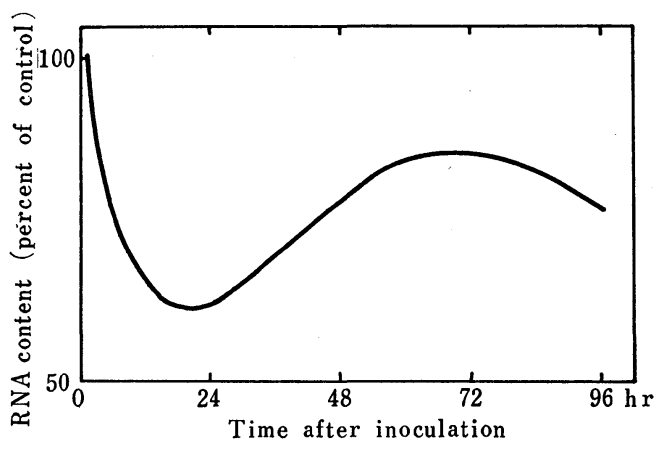

Fig. 2. Change of cellular RNA content in infected tissue.

\section{Base composition of DNA in the CMV infected cells \\ The base composition of nuclear DNA} was characterized by a high content of adenine and thymine (Table 1). As shown in Table 1, the purine and pyrimidine composition of DNA from the infected tobacco leaves did not differ from that of the healthy leaves. These results suggest that the infection does not significantly alter the purine and pyrimidine composition of DNA over the period of $72 \mathrm{hr}$ after infection.

The results of the $\mathrm{CsC} 1$ density gradient fractionation of DNA are shown in Fig. 3 . The buoyant density of the nuclear DNA isolated from healthy and infected leaves ranged from 1.695 to $1.699 \mathrm{~g} / \mathrm{m} l$. The average value in 5 experiments was $1.696 \mathrm{~g} / \mathrm{m} l$, and the buoyant density between the healthy and infected leaf DNA did not differ significantly. Furthermore, the increase in DNA occurring shortly after infection was bounded with histone. Free DNA, i. e., DNA not combined with histone, did not increase for $8 \mathrm{hr}$ (Table 2). From these results, it appears that the suppression of host cell RNA synthesis during early stage of the infection is not due to a change of DNA.

\section{Changes of histone content in CMV infected cells}

Experiments were conducted by utilizing a microspectrophotometric method to determine if the histone content in the nucleus is altered by the infection. The results are shown in 


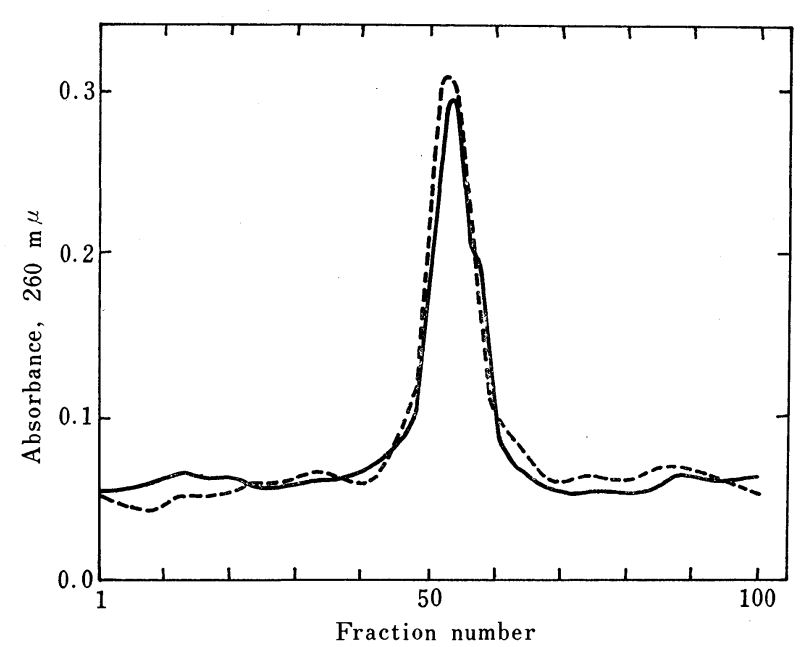

Fig. 3. Density gradient centrifugation in $\mathrm{CsCl}$ of nuclear DNA from tobacco leaves.

The DNA was extracted from healthy and infected leaves. Centrifugation was run for $48 \mathrm{hr}$ at $36,000 \mathrm{rpm}$ in the RPS 40 rotor of Hitachi model $55 \mathrm{P}$ centrifuge at $25^{\circ} \mathrm{C}$. The absorbance at $260 \mathrm{~m} \mu$ was measured after the collection of fractions throughout the gradient. Density increase toward the left.

- : DNA isolated from healthy leaves. .......... DNA, $8 \mathrm{hr}$ after inoculation.

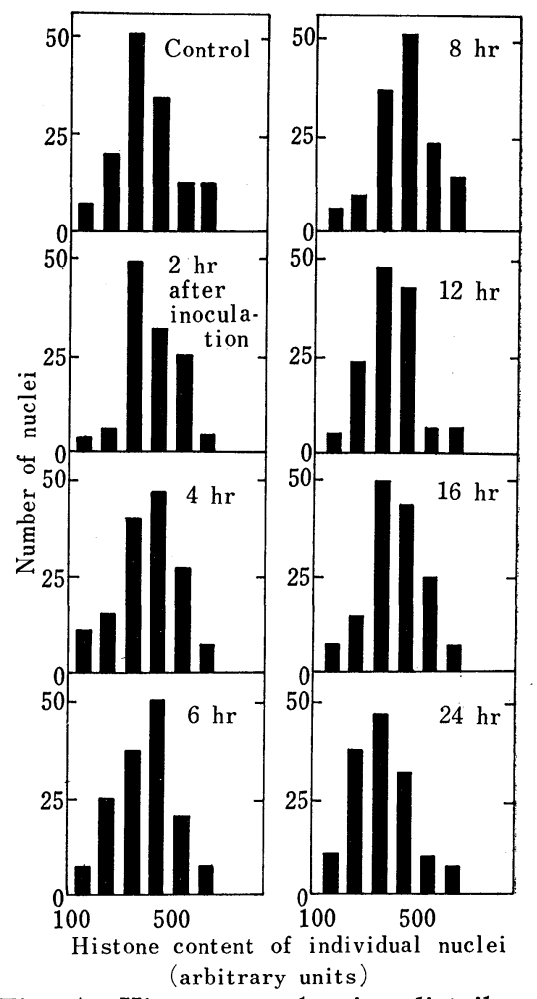

Fig. 4. Histogram showing distribution of nuclei containing various amounts of histone at each period after the inoculation.

Fig. 4. Within $2 \mathrm{hr}$ following the inoculation, the histone content did not change. Namely, in this period, there appears to be no significant difference in the content of nuclear histone between the infected and normal cells. The peak of histone in both the infected and healthy cells was equally evident at 200-300 arbitrary units. After $4 \mathrm{hr}$, however, the histone content in the infected cells increased significantly and the peak shifted to 400-500 units. By the end of $24 \mathrm{hr}$, it returned again to the distribution pattern similar to that of the normal cells. The change in the histone content of the nucleus occurred concurrently with the change in the DNA content ${ }^{17)}$. However, the alteration of histone synthesis was not only quantitative but also qualitative; the fractionation of histone on carboxymethylcellulose column showed an increase in the arginine-rich fractions. The results of a fractionation with the whole histone preparations isolated from the healthy and infected leaves are shown in Fig. 5 . The peak $\mathrm{fX}$ contained only about $1 \%$ of the total nitrogen taken, and this initial peak was considered to be a contaminant ${ }^{11}$. Step (2) then removed the 1ysine-rich histone as two peaks, $\mathrm{f} 1 \mathrm{~A}$ and f1B. The yield of the arginine-rich histones, $\mathrm{f} 3$ and $\mathrm{f} 4$, was about $30 \%$ of the total histone isolated from the healthy leaves taken for chromatography, and about $40 \%$ at $72 \mathrm{hr}$ after infection. The ratio of the protein in the arginine-rich fraction to the protein in the lysine-rich fraction of the histone isolated from the healthy leaves was 0.6 , whereas that of the infected leaves increased as the infection process proceeded; it was $0.8,0.9$ and 1.0 after 5,20 and $72 \mathrm{hr}$ respectively (Table 3 ). These compositional changes were also. 


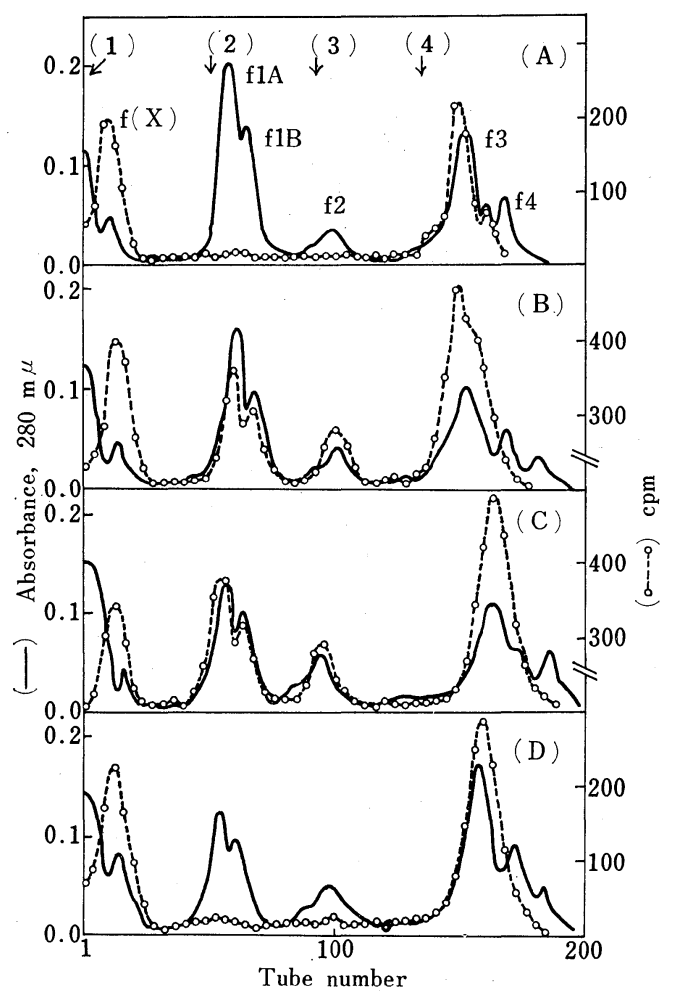

Fig. 5. Elution profile of histone from CMC column of histones isolated from incubated leaf disk.

Elution scheme used : (1) $0.1 \mathrm{M}$ sodium acetate buffer, $\mathrm{pH} 4.2$; (2) sodium acetate-NaCl buffer, $\mathrm{pH} 4.2$; (3) $0.01 \mathrm{~N}$ $\mathrm{HCl}$, and (4) $0.02 \mathrm{~N} \mathrm{HCl}$.

Protein concentration of each fraction was determined by optical density at 280 $\mathrm{m} \mu$. (A): healthy leaves histone, (B): infected leaves histone, $8 \mathrm{hr}$ after inoculation, (C) : $12 \mathrm{hr}$ after inoculation, (D) : $72 \mathrm{hr}$ after inoculation.

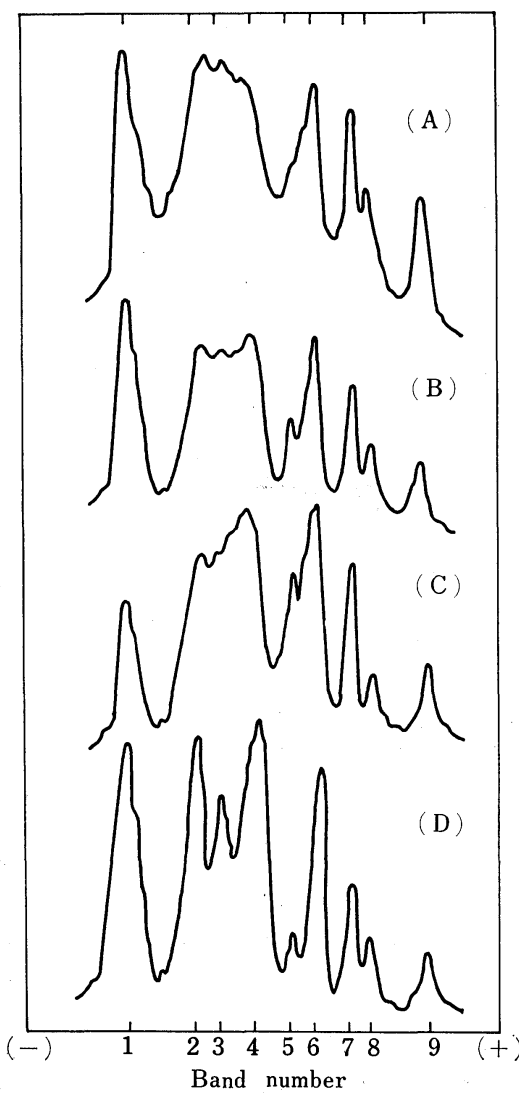

Fig. 6. Densitometeric scanning of histone bands in polyacrylamide gels electrophoresis.

Disk electrophoresis was performed in $15 \%$ polyacrylamide gels containing $6 \mathrm{M}$ urea. Gels were stained with amidoblack and destained electrophoretically. A shows the electrophoretic fractionation of healthy leaf histone. $\mathrm{B}$ to $\mathrm{D}$, the electrophoretic fractionation of histone isolated from infected leaves 8,12 and $72 \mathrm{hr}$ after inoculation respectively. Peak at far left indicates the origin of the gel.

confirmed by disk electrophoresis on polyacrylamide gels. These results are shown in Fig. 6 . Similar results were obtained from the analysis of amino acid composition of the histone isolated from CMV infected cells as shown in Table 4. Although the hydrolysis of histone resulted in a partial degradation of serine and threonine, their losses were relatively so small that no correction was made for them. The histone isolated from the healthy and infected tobacco leaves equally contained about $21-24 \%$ basic amino acid, principally 1ysine and arginine. Lysine to arginine ratios in the histone isolated from the infected and healthy leaves were approximately $1: 5$ and $1: 8$, respectively. The arginine content in histone was found to be markedly increased in the infected cells. 
Table 3. Protein content of the fraction from histone

\begin{tabular}{cccc}
\hline \hline Time after inoculation & Fraction 1,2 & Fraction 3,4 & F 1, 2/F 3,4 \\
\hline Control & $233.1 \mu \mathrm{g}$ & $139.8 \mu \mathrm{g}$ & 0.6 \\
$5 \mathrm{hr}$ & 199.0 & 168.5 & 0.8 \\
$20 \mathrm{hr}$ & 180.0 & 170.0 & 0.9 \\
$72 \mathrm{hr}$ & 178.6 & 180.3 & 1.01 \\
\hline
\end{tabular}

The protein content in each fraction is taken as a measure of the fresh weight $(250 \mathrm{~g})$. Protein was estimated by Folin reagent.

Table 4. Amino acid composition of histone (moles \%)

\begin{tabular}{lcc}
\hline \hline Amino acid & Healthy tobacco histone & Infected tobacco histonea \\
\hline Aspartic acid & 6.8 & 6.4 \\
Glutamic acid & 9.6 & 9.4 \\
Glycine & 9.0 & 8.4 \\
Alanine & 11.5 & 11.1 \\
Valine & 7.4 & 7.1 \\
Leucine & 6.6 & 6.0 \\
Isoleucine & 4.7 & 4.1 \\
Phenylalanine & 2.3 & 2.7 \\
Tyrosine & 3.5 & 2.9 \\
Serine & 6.1 & 6.2 \\
Threonine & 6.2 & 6.2 \\
Proline & 4.1 & 3.3 \\
Methionine & 1.1 & 0.8 \\
Cystine & 0.1 & + \\
Arginine & 6.8 & 9.2 \\
Histidine & 1.9 & 2.1 \\
Lysine & 12.3 & 14.1 \\
Lysine/arginine & 1.8 & 1.5 \\
Basic/acidic & 1.28 & 1.60 \\
\hline a) Histone isolated from tobacco leaves infected with CMV, $24 \mathrm{hr}$ after \\
inoculation.
\end{tabular}

\section{Incorporation of ${ }^{14} \mathrm{C}$-amino acid into the nuclear histones}

The data for the incorporation of ${ }^{14} \mathrm{C}$-labeled amino acid into the histone fractions of the chromatin isolated from CMV-infected cell nuclei fraction are shown in Fig. 5 . In the increasing stage of DNA during the first $12 \mathrm{hr}$ after infection, all histone fractions were labeled. The radioactivities found in the histone of fractions 3 and 4 were much greater than those of the controls. But, in the stationary stage (after $72 \mathrm{hr}$ ), only fractions 3 and 4 were labeled like the histone fractions from the control cells. That the synthesis of histones in fractions $1 \mathrm{~A}$ and $1 \mathrm{~B}$ related directly with the DNA increase may be indicated by the above experiments. Thus, the histones of fractions 3 and 4 are actively synthesized, especially in the early stage of infection.

\section{Effects of added histone on the RNA synthesis}

A study was conducted to determine whether or not the histone inhibit RNA synthesis. Since it was difficult to isolate the nuclei in a pure from tobacco leaves, calf thymus nuclei were used in the present study. The synthesis of RNA in isolated calf thymus nuclei was followed using ${ }^{14} \mathrm{C}$-adenosine. The incorporation of this labeled compound into nuclear RNA was allowed to proceed for $30 \mathrm{~min}$ at $37^{\circ} \mathrm{C}$ in the incubation medium. When tobacco histones were added to the incubation medium, the synthesis of RNA was inhibited slightly (Fig. 7). 


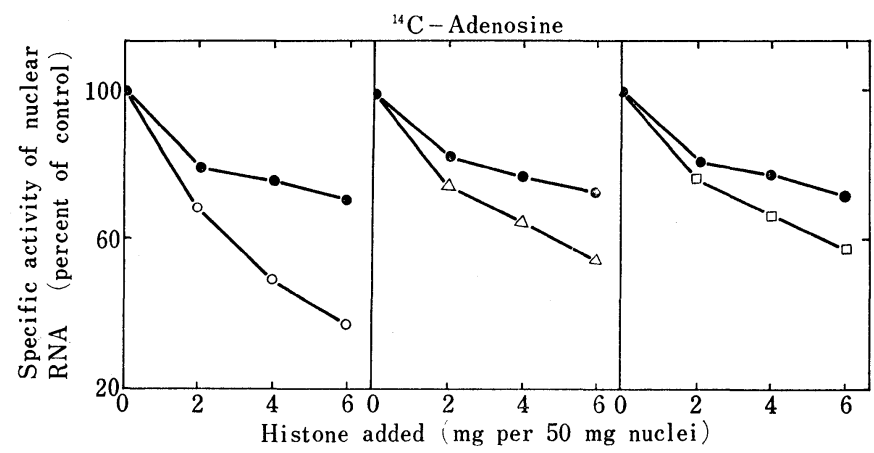

Fig. 7. The effects of some histone on RNA synthesis in isolated thymus nuclei.

The amount of histone added is piotted against the relative specific activity of the total nuclear RNA.

: Healthy tobacco histone.

$\bigcirc-\bigcirc$ : Calf thymus histone.

$\triangle-\triangle: \mathrm{CMV}$ infected tobacco histone, $12 \mathrm{hr}$ after inoculation.

$\square-\square:$ CMV infected tobacco histone, $72 \mathrm{hr}$ after inoculation.

However, the inhibitory effect of the histones isolated from the healthy tobacco cells differed from that of CMV infected cells. The histone isolated from the CMV-infected cells inhibited RNA synthesis much more greatly than the histone from the normal cells.

\section{Discussion}

The results obtained in the present study show that the host cell RNA content is reduced by $40 \%$ or more during the CMV infection. The reduction in cellular RNA content may result from 3 possibilities : 1) qualitative and quantitative changes in the DNA which primes RNA synthesis; 2) regulation of enzymes in the RNA synthesizing system, and 3 ) degradation of RNA by enzymes such as ribonucleases.

The results of the present study indicate that the suppression of the host cell RNA synthesis induced by the CMV-infection is neither due to quantitative change of DNA nor to qualitative alteration of DNA. These results are consistent with those reported by Holland ${ }^{9}$ in poliovirus-infected HeLa cells.

Previous work ${ }^{17)}$ in our laboratory has shown that the amount of DNA in the nucleus increased temporarily after $\mathrm{CMV}$-infection and also that the amount of DNA in the nucleus changed concurrently with the change of histone content. Huang and Bonner ${ }^{10)}$, working with histone isolated from pea seedling, indicated that the DNA fully combined with an appropriate histone was not transcribed by RNA polymerase. Since the results of the present study showed that the free DNA, not combined with histone, did not increase and that only the DNA fully combined with histone increased, it is not likely that the increase of the DNAhistone complex in the nucleus is linked to the suppression of cellular RNA synthesis.

Furthermore, as reported previously ${ }^{18)}$, the increase of ribonuclease activity in tobacco leaf does not appear to be a specific and necessary concomitant of the infection process. Stimulation of ribonuclease activity, regardless of its cause, did not reduce cellular RNA content. Eventually, the increase in ribonuclease activity of infected cells does not seem to explain the observed depression of RNA synthesis.

Huang and Bonner ${ }^{10)}$, and Allfrey et al. ${ }^{2)}$ reported that the synthesis of RNA in nucleus 
was regulated by histone and that when the histone was removed, the synthesis of RNA increased. Chalkley and Maurer ${ }^{5)}$ classified histones into 2 groups on the basis of their different biochemical properties : one group, named "fractions 3 and 4", has a fast turnover without DNA replication; and the other, named " $1 \mathrm{~A}$ and $1 \mathrm{~B}$ fractions", has no turnover except during DNA replication. The 3 and 4 fractions contain arginine-rich histone ${ }^{11)}$. In addition, it has been shown that arginine-rich histone had a greater inhibitory effect on RNA synthesis as compared with other types of histones ${ }^{2}$. The histone which was altered by the CMV-infection corresponds to a fast turnover histone, since the histone isolated from infected cell had a much greater inhibitory effect on RNA synthesis than the normal one. In virusinfected cells, the DNA-primed RNA polymerase might be prevented from contact with DNA by the modified histone that occurs during infection. It is our hypothesis that the suppression of normal cell RNA synthesis by viral infection is due to the compositional change of histone which is promptly induced by the viral infection.

\section{Acknowledgement}

The authors are deeply grateful to Dr. Kensuke Shimura, Professor of Biochemistry, for his valuable advice and indebted to Mr. Toshio Suzuki for his assistance.

\section{Literature cited}

1. Alfert, M. and Geschwind, I. I. (1953). Proc. Natl. Acad. Sci. U. S. 39 : 991-999.

2. Allfrey, V. G., Littau, V. C. and Mirsky, A. E. (1963). Ibid. 49:414-421.

3. Bablanian, R., Eggers, H. J. and Tamm, I. (1965). Virology $26: 100$.

4. Baltimore, D. and Franklin, R. M. (1962). Proc. Natl. Acad. Sci. U. S. $48: 1930-1938$.

5. Chalkley, G. R. and Maurer, H. R. (1965). Ibid. 54 : 498-505.

6. Franklin, R. M. and Baltimore, D. (1962). Cold Spring Harber Symp. Quant. Biol. 27 : 175-194.

7. Franklin, R. M. and Rosner, J. (1962). Biochim. Biophys. Acta. 55 : 240-241.

8. Holland, J. J. (1962). Biochem. Biophys. Res. Commun. $6: 196-200$.

9. Holland, J. J. (1962). Ibid. $9: 556-562$.

10. Huang, R. C. and Bonner, J. (1962). Proc. Natl. Acad. Sci. U. S. $48: 1216$.

11. Johns, E. W., Phillips, D. M. P., Simson, P. and Butler, J. A. V. (1960). Biochem. J. $77: 631-635$.

12. Kerr, S. E. and Seraidarian, K. (1945): J. Biol. Chem. $159: 211$.

13. Lowry, D. H., Rosebrough, N. J., Farr, A. L. and Randa11, R. J. (1951). Ibid. $193: 265-$ 275 .

14. Marmur, J. (1961). J. Mol. Biol. $3: 208-218$.

15. Marshak, A. and Vogel, H. J. (1951). J. Biol. Chem. $189: 597$.

16. Mendelson, M. L. (1958). J. Biophys. Biochem. Cytol. $4:$ 407-415.

17. Misawa, T., Kato, S. and Suzuki, T. (1966). Tohoku J. Agr. Res. 16 : 256-274.

18. Misawa, T., Kato, S. and Suzuki, T. (1968). Jubilee Publ. in Commemoration of 60 th Birthday of Prof. M. Sakamoto. Sendai. pp. 183-189.

19. Ogur, M. and Rosen, G. (1950). Arch. Biochem. $25: 262-278$.

20. Reisfeld, R. A., Lewis N. J. and Williams, D. E. (1962). Nature $195: 281-283$.

21. Salzman, N. P., Lockort, R. Z. and Sebring, E. D. (1959). Virology 9 : 244-259. 
22. Wess, S. B. (1960). Proc. Nat1. Acad. Sci. U. S. $46: 1020-1030$.

23. Zubay, G. and Doty, P. (1959). J. Mol. Biol. 1:1-20.

\section{和文摘要}

植物ウイルスの感染と増殖に関する研究

IV. CMV 感染による細胞 RNA 合成の抑制

加 藤 盛 三 沢 正 生

CMV 感染タバコ葉細胞に扣ける RNA 合成の抑制について検討した。

1. CMV 感染タバコ葉細胞の RNA 含量は感染直後から 24 時間までは急速に低下寸るが，それ以後は漸 增する。この増加は主としてウイルス RNA の合成增加によるものと思われる。

2. 細胞核 DNA の塩基組成, buoyant density は CMV の感染によってまったく変化しない。した がって感染細胞の DNA 依存の RNA 合成の低下は，DNA の質的変化によるものではないと推定される。

3. 感染細胞でのヒストン合成は DNA 合成に伴って変化するが，ヒストンは DNA と異なり，量的だ けでなく，質的にも変動する。すなわちヒストンの各分画中，感染によって高アルギニンヒストンの分画が いちじるしく增加してくる。

4.タバコのヒストンは calf thymus の細胞核系での RNA 合成を阻害する。阻害効果は健全細胞よ り感染細胞からのヒストンで顕著である。

以上の諸結果から, CMV 感染細胞でみられる細胞の RNA 合成の抑制は, 感染によるヒストンの質的 な変動に起因すると推定された。 